The Israeli Journal of Aquaculture IJA.73.2021. 1426167, 9 pages

CCBY-NC-ND-4.0 • https://doi.org/10.46989/001c.24939

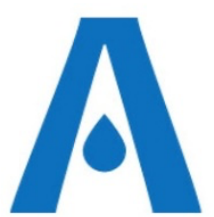

The $I J A$ is a peer-reviewed open-access, electronic journal, freely available without charge to users

Produced by the AquacultureHub non-profit Foundation Sale of $I J A$ papers is strictly forbidden

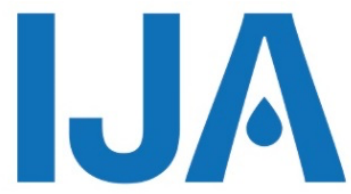

\title{
Assessment of heavy metals found in commonly consumed fishes from Lake Lanao, Philippines
}

\author{
Melencio C. Jalova, Jri ${ }^{1}$, Abdulnasser D. Lomantong ${ }^{1}$, Lorelie G. \\ Calibo², Ma-ann M. Camarin ${ }^{3 *}$
}

${ }^{1}$ College of Forestry and Environmental Studies, Mindanao State University, Marawi City, Lanao del Sur, Philippines

2 College of Natural Sciences and Mathematics, Mindanao State University, Marawi City, Lanao del Sur, Philippines

${ }^{3}$ College of Fisheries, Mindanao State University, Marawi City, Lanao del Sur, Philippines

Key words: health index, lake, contamination, analysis, non-carcinogenic

\begin{abstract}
This study was carried out to assess potential heavy metal contamination in the muscles of three commonly consumed fish species in Lake Lanao and to determine associated health risks that may endanger local community residents who consume these fishes. The concentrations of Arsenic (As), Cadmium (Cd), Chromium $(\mathrm{Cr})$, Mercury $(\mathrm{Hg})$ and Lead $(\mathrm{Pb})$ were assessed in the muscles of Glossogobius giurus, Oreochromis niloticus and Giuris margaritacea and were measured via atomic absorption spectrophotometry. Statistical analysis showed that heavy metal concentrations in the muscles of the three fish species collected from the two different locations in the lake are not significantly different $(P>0.05)$ except for $O$. niloticus. Recorded amounts of the five heavy metals in the present study were lower than the maximum and standard levels except for $\mathrm{Pb}$. Four ( $\mathrm{As}, \mathrm{Cd}, \mathrm{Cr}$, and $\mathrm{Hg}$ ) among the five pollutants of concern obtained Non-carcinogenic Hazard Quotient (NHQ) values that are less than one, while NHQ values for $\mathrm{Pb}$ range between 815.6 and 1396.03 for all fish samples obtained from both sampling stations. The continued consumption of G. giuris, $O$. niloticus and G. margaritacea collected from Marawi City and Tugaya, Lanao del Sur posed a high likelihood for local residents to contract adverse non-carcinogenic impacts, specifically by $\mathrm{Pb}$. This does not necessarily hold true for the whole of Lake Lanao however, due to limitations related to representativeness. Steps should be taken to manage the risks posed by the consumption of $G$. giuris, $O$. niloticus, and G. margaritacea from Marawi City and Tugaya, Lanao del Sur, especially in consideration of vulnerable groups such as children, pregnant women and their developing fetus, and people with existing health conditions.
\end{abstract}

\footnotetext{
* Corresponding author. M.M Camarin, email: ann.camarin@msumain.edu.ph
} 


\section{Introduction}

Lakes are essential to human well-being. They provide a wide range of ecosystem services including flood control, biodiversity, climate change mitigation, river flow regulation, hydropower supply, as well as water purification and storage. In recent decades, emerging global threats closely linked to anthropogenic pressures such as land-use intensification, nutrient enrichment, hydrological modification, aquaculture and fisheries, climate change, and water depletion have been driving forces of changes in lakes and reservoirs. These pressures have caused habitat loss and degradation, eutrophication and pollution, food web alteration, and physical degradation in many inland bodies.

Another emerging threat to lake sustainability is the ever-increasing number of emerging contaminants brought about by technological advances which add more waste products and chemicals into the environment. These contaminants are new compounds with little environmental regulation and whose impacts are still not completely clear. They range from personal care products and illicit drugs to endocrine disrupting compounds, which can pose a serious threat to both aquatic ecosystems and human health. Additionally, the presence of micro-plastics and anti-microbial resistance in lakes are increasing because of the widespread use of these products. Agriculture, aquaculture, and livelihood development caused a higher level of antimicrobial resistance in surface water systems, consequently, causing health problems to water users (Ho and Goethals, 2019).

Fishing, being one of the most important ecosystem services provided by inland aquatic ecosystems, contributes significantly in meeting the basic human need for food. With the increasing world population, fish consumption meets the demand for food among lakeshore communities while also serving as a substitute for beef, pork and another animal protein (Béné et al. 2015).

Lake Lanao is the largest lake in Mindanao with a total area of $347 \mathrm{sq} \mathrm{km}$ and is considered as one of the 17 ancient lakes on earth. Known as a pre-historic and socioculturally significant lake, Lake Lanao shelters a great biodiversity of aquatic life forms. Through the years however, the lake has not been spared from various anthropogenic activities associated with the growing demand of the lake's resources-the water for domestic and agricultural use and hydro-power generation, contact recreation, boating, laundry and bathing, ritual use, water sports, fishes for domestic consumption and livelihood-among other numerous related uses. (Angagao et al., 2017).

Heavy metals are metallic chemical elements that occur as natural constituents of the earth's crust. They are toxic even at low concentrations and are considered as persistent environmental pollutants since they cannot be degraded or destroyed. As trace elements, some heavy metals are essential to maintain the metabolism of the human body. However, these can lead to poisoning at higher concentrations. Their toxicity depends on several factors including the dose, route of exposure, chemical species, as well as the age, gender, genetics, and nutritional status of exposed individuals (Tchounwou et al., 2012).

The bio-toxic effects associated with heavy metals poisoning (cadmium, lead, arsenic, mercury, zinc, copper and aluminum) have the following general signs: gastrointestinal (GI) disorders, diarrhea, stomatitis, tremor, hemoglobinuria (condition causing a rust-red color to stool), ataxia, paralysis, vomiting and convulsion, depression, and pneumonia when volatile vapors and fumes are inhaled (Duruibe et al., 2007; McCluggage, 1991). The nature of effects could be toxic (acute, chronic or sub-chronic), neurotoxic, carcinogenic, mutagenic or teratogenic.

The dangers associated with human consumption of potentially contaminated fishes could be averted with the application of scientific inquiries that are appropriate and timely. This study sought to assess potential risks to public health, the results of which will also serve to inform and forewarn the Meranao lakeshore communities and their respective local governments about the possible contamination of fishery resources in Lake Lanao.

The study was limited on the determination of heavy metal concentrations in three commonly consumed fishes sourced in Lake Lanao. The findings were compared against the recommended standard and maximum levels allowed in fishes and other foods. Furthermore, health risks were evaluated only in consideration of human consumption of fishes which are potentially contaminated with $\mathrm{As}, \mathrm{Cd}, \mathrm{Cr}, \mathrm{Hg}$, and $\mathrm{Pb}$. 
Study site

\section{Materials and Methods}

The study was conducted in two sampling sites-first of which is the lakeshore of Marawi City - an urban community and known as the center of trade, commerce, and industry in the province of Lanao del Sur (Figure 1). The first sampling site/station is located proximate to the most affected area during the Marawi armed conflict that occurred in 1997 instigated by ISIS-inspired rebels. This point is also located nearest to the source or headwaters of the Agus river. The second sampling site/station is located in the lakeshore of the Municipality of Tugaya, which is about $26.3 \mathrm{~km}$ from Marawi City. Tugaya is known for manufacturing traditional Maranao arts and crafts, such as back-strap loom weaving, tapestry weaving, and other kinds of handmade textile manufacture; foundry casting of various forms of brass or bronze vessels, instruments, and decorative items; wood-carving and mother-of-pearl inlay work; metalwork and silver- and gold-smiting.

Collection of samples

Commonly consumed fish species (10-15 individuals of each species) namely, Kadurog (Glossobius giuris; average weight $0.13 \pm 0.07 \mathrm{~kg}$ and average length $192.0 \pm 44.2 \mathrm{~cm}$ ), Nile tilapia (Oreochromis niloticus; $0.30 \pm 0.17 \mathrm{~kg}$ and $195.6 \pm 47.1 \mathrm{~cm}$ ) and Katolong (Giuris margaritacea; $0.034 \pm 0.011 \mathrm{~kg}$ and $112.4 \pm 12.6 \mathrm{~cm}$ ) were collected from three sub-stations located in each of the two sampling stations. Fish samples were transported to the laboratory in boxes filled with ice. The mean length and weight of the fish were recorded. All fish samples were kept at low temperature until analysis (Öztürk et al., 2009). The fish samples were thoroughly washed with distilled water to remove any adhering contaminants, and they were put on a dissection tray and thawed at room temperature. They were dissected using a knife and forceps, and the intestine, guts and bones were removed. Muscle tissues of fish (dorsal and ventral muscle) were used in this study since it is the most edible part of the fish (Listrat et al., 2016). All the samples were immediately transported to a competent and duly-accredited laboratory for the processing of the samples and determination of heavy metals.

Sample preparation

Muscle portion was put in a clean Petri dish and dried in an oven at $120 \pm 2^{\circ} \mathrm{C}$ for 48 hours through which a constant weight was obtained. Before acid digestion, the dried muscle was pulverized to a fine powder using a mortar and pestle and stored in a freezer $\left(-4^{\circ} \mathrm{C}\right)$ prior to analysis. One gram of each sample (powder) was mixed with $20 \mathrm{ml}$ distilled water and diluted using $\mathrm{HNO} 3(55 \%)$ and $\mathrm{HClO} 4(70 \%)$ mixed concentration in $100 \mathrm{ml}$ Erlenmeyer flask on a heating digester $\left(200\right.$ to $\left.250^{\circ} \mathrm{C}\right)$ until a clear solution was obtained and the volume was reduced to approximately $15 \mathrm{ml}$. This solution was then filtered using Whatman no. 1 filter paper into the volumetric flask and diluted to $50 \mathrm{ml}$. The prepared samples were analyzed using Atomic Absorption Spectrophotometer (Perkin Elmer Inc.).

Data analysis and comparison

Descriptive statistics such as average and standard deviation values were calculated. Finally, the mean concentration of heavy metals found in the different fish samples were compared to the recommended accepted value provided by FAO/WHO to check if the present value of heavy metals are within the standard and tolerable limits or not.

Health risk assessment

The health risks associated with ingesting $\mathrm{As}, \mathrm{Cd}, \mathrm{Cr}, \mathrm{Hg}$, and $\mathrm{Pb}$ in fishes from Marawi City and Tugaya, Lanao del Sur, was assessed using the United States Environmental Protection Agency (USEPA) risk assessment methodology (USEPA, 1989), as used in several studies (Molina, 2012; Iqbal and Shah, 2013; Alidadi et al., 2019), with the following numeric expressions:

$$
N H Q_{\text {ing }}=\frac{\mathrm{CDI}_{\text {ing }}}{\mathrm{Rfd}_{\mathrm{ing}}}
$$


where $N H Q_{i n g}$ : non-carcinogenic hazard quotient (ingestion), also known as $\mathrm{HQ}$; $R f d_{\text {ing }}$ : chronic (oral) reference dose for the toxicant to which human population can be exposed to over a lifetime without any appreciable risk, expressed in $\mathrm{mg} / \mathrm{kg}$-day ; $C D I_{\text {ing }}$ : chronic daily intake of the toxicant, in this case via ingestion, expressed in $\mathrm{mg} / \mathrm{kg}$-day, also known as exposure dose (Exp).

$$
\mathrm{CDI}_{\text {ing }}=\frac{\mathrm{C}_{\text {ing }} \times \mathrm{IR} \times \mathrm{EF} \times \mathrm{ED} \times \mathrm{CF}}{\mathrm{BW} \times \mathrm{LT} \times \mathrm{CF}}
$$

where $C_{\text {ing: }}$ : concentration of heavy metal in fish $(\mathrm{mg} / \mathrm{kg}) ; I R$ : ingestion rate (per capita) for 2013 (FAO, 2020), for freshwater fish consumption $=22.11 \mathrm{~g} / \mathrm{day}(8.07 \mathrm{~kg} / \mathrm{yr}) ; E F$ : exposure frequency (350 days per year); $E D$ : exposure duration (30 years); CF: conversion factor (kg/1000g and 365 days/year); BW: body weight, approximately $65 \mathrm{~kg}$ for an adult Filipino; $L T$ : lifetime (average) or average time (AT), 30 years for non-carcinogenic health effects. The Rfd values for the consumption of heavy metals are the following: $\mathrm{Ar}=0.0003$ $\mathrm{mg} / \mathrm{kg}$-day, Cadmium $=0.001 \mathrm{mg} / \mathrm{kg}$-day, $\mathrm{Cr}=0.003 \mathrm{mg} / \mathrm{kg}$-day, $\mathrm{Hg}=0.0001 \mathrm{mg} / \mathrm{kg}$ day, and $\mathrm{Pb}=0.0000001 \mathrm{mg} / \mathrm{kg}$-day.

Since NHQ is only a numeric estimate of the non-carcinogenic toxicity potential posed by a single element within one route of exposure, and the potential for systemic toxicity can be posed by multiple chemical exposure (Asante-Duah, 2017), the total non-carcinogenic health risk or hazard index (HI) was also computed,

$$
H I_{\text {ing }}=\sum_{i=1}^{n} N H Q i n g
$$

where $\mathrm{HI}_{\text {ing }}$ : hazard index via ingestion (unitless) estimates risks posed by aggregate or cumulative exposures. This is done to assess cumulative risk, provided that the criteria for conducting this assessment is met. (Asante-Duah, 2017; Clayton et al., 2002; USEPA, 2020).

$\mathrm{NHQ}$ and $\mathrm{HI}$ indicate the likelihood for harm that will arise due to non-carcinogenic effects resulting from exposure to chemicals via different pathways. When NHQ/HI $\leq 1$, there is no appreciable risk for harm, and in the case of this study, due to ingesting the organisms contaminated with the pollutants of concern. When NHQ/HI $>1$, this means that there is an increased potential that adverse effects to human health will occur. The higher the value, the greater is the likelihood for adverse non-carcinogenic health effects (USEPA, 1989; Asante-Duah, 2017).

It should be noted that for the concentrations used in the calculation of the indices, values lower than the lowest detection limit of the equipment (<lowest detection limit) used for the analysis was replaced with the lowest value that can be detected (e.g., 0.025 for $<0.025,0.25$ for $<0.25$ and so on). This approach was adapted as recommended by Asante-Duah (2017), since based on the other test results, the pollutants in question are present. Replacing the "<lowest detection limit" with zero would discount the presence of the pollutants entirely, when it could have been present albeit in amounts lower than what the equipment can quantify.

\section{Results}

Results on the analysis for heavy metal content in the fish samples collected are shown in Table 1. The mean values for As (mg/kg) in G. giuris are 0.283 and 0.294 ; in O. niloticus are 0.124 and 0.33 ; while in G. margaritacea are valued at 0.23 and 0.058 in Marawi City and Tugaya, respectively. Mean values of $\mathrm{Cd}(\mathrm{mg} / \mathrm{kg})$ in all the fish samples from the two 
different locations are below the detectable limit. The same is true in the case of $\mathrm{Cr}$ except in Marawi City where $\mathrm{Cr}$ mean values are 0.35 and 0.314 for G. giuris and $\mathrm{O}$. niloticus, respectively. $\mathrm{Hg}$ mean values in Marawi City are 0.03 and 0.013 for G. giuris and G. margaritacea, respectively. In Tugaya, all fish samples show concentrations that are below the detectable limit except for $\mathrm{G}$. margaritacea which has a mean value of $\mathrm{Hg}$ of 0.012 . In the case of $\mathrm{Pb}$, the mean values for all the fish samples from Marawi are shown to be below the detectable limit, while in Tugaya, G. giuris and $O$. niloticus, both have $\mathrm{Pb}$ values of 0.252 respectively. Generally, the concentrations of $\mathrm{As}, \mathrm{Cd}, \mathrm{Cr}, \mathrm{Hg}$ and $\mathrm{Pb}$ in the muscle of the three fish species analyzed from the two different sampling sites are not significantly different $(P>0.05)$ except in $O$. niloticus from Tugaya wherein $A s$ and $P b$ values were significantly higher compared to Marawi samples.

Table 2 shows the maximum and standard levels in ( $\mathrm{mg} / \mathrm{kg}$ wet weight) of heavy metals in fish described in literature and the range of concentrations found in muscle fish collected from the three sampling sites. As shown in the table, recorded amounts of the five heavy metals in the present study are lower than the maximum and standard levels except for $\mathrm{Pb}$ where only $0.30 \mathrm{mg} / \mathrm{kg}$ are considered as the standard values while in the present study a range of values of $0.25-0.428 \mathrm{mg} / \mathrm{kg}$ are recorded.

Table 3 shows that four ( $\mathrm{As}, \mathrm{Cd}, \mathrm{Cr}$, and $\mathrm{Hg}$ ) among the five pollutants of concern have an NHQ that is less than one. However, Pb has an NHQ that exceeded one for all fish samples obtained from all locations, with values ranging from 815.60 for ingestion of $G$. margaritacea to 1396.03 from ingestion of 0 . niloticus collected from Tugaya. Similar findings of $\mathrm{NHQ}$ values of greater than one for $\mathrm{Pb}$ in mudfish are also reported in Laguna de Bay in a study conducted by Molina (2012).

The health risk was only assessed in consideration of exposure to $\mathrm{As}, \mathrm{Cd}, \mathrm{Cr}, \mathrm{Hg}$, and $\mathrm{Pb}$ via ingestion of fish (Table 4). Overall, the mean values of heavy metals in most cases are considerably lower than the standard permissible level except for $\mathrm{Pb}$.

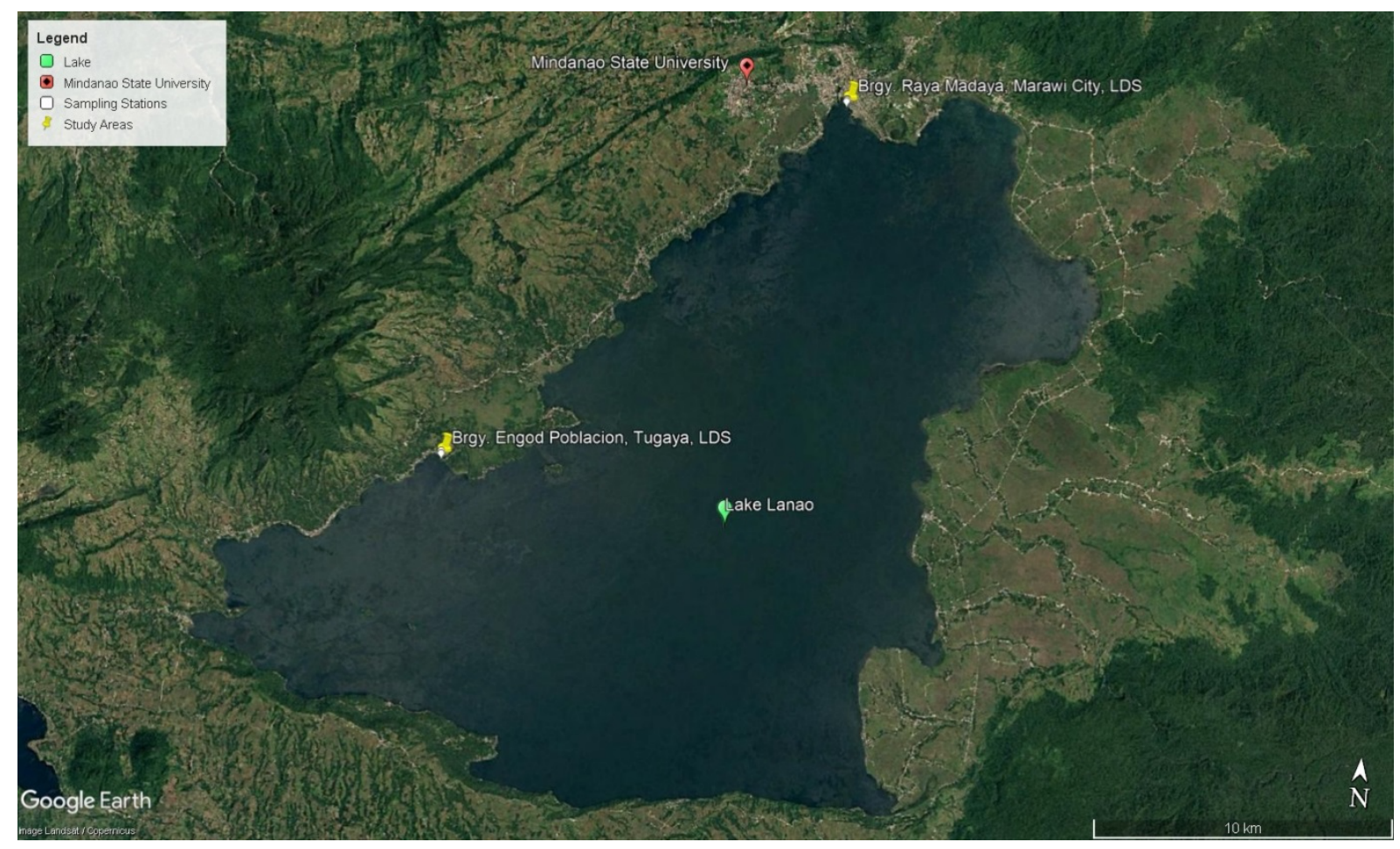

Figure 1 Satellite view image of Lake Lanao showing the sampling sites. 
Table 1 Mean concentration of As, Cd, Cr, Pb, $\mathrm{Hg}$ (mg/kg wet wt.) in muscle tissues of three fish species collected from Marawi and Tugaya.

\begin{tabular}{|c|c|c|c|c|c|c|}
\hline \multirow[t]{2}{*}{ Location } & \multirow[t]{2}{*}{ Samples } & \multicolumn{5}{|c|}{ Heavy metals } \\
\hline & & As & $\mathrm{Cd}$ & $\mathrm{Cr}$ & $\mathrm{Hg}$ & $\mathrm{Pb}$ \\
\hline \multirow[t]{3}{*}{ Marawi } & Glossobius giuris & 0.283 & 0.025 & 0.35 & 0.022 & 0.25 \\
\hline & Oreochromis niloticus & 0.124 & 0.025 & 0.314 & 0.01 & 0.25 \\
\hline & Giuris margaritacea & 0.23 & 0.025 & 0.25 & 0.012 & 0.25 \\
\hline \multirow[t]{3}{*}{ Tugaya } & Glossobius giuris & 0.294 & 0.025 & 0.25 & 0.01 & 0.252 \\
\hline & Oreochromis niloticus & 0.33 & 0.025 & 0.25 & 0.01 & 0.428 \\
\hline & Giuris margaritacea & 0.058 & 0.025 & 0.25 & 0.012 & 0.252 \\
\hline
\end{tabular}

*All tissue concentrations are in $\mathrm{mg} / \mathrm{kg}$ wet weight.

Table 2 Maximum and standard levels in ( $\mathrm{mg} / \mathrm{kg}$ wet weight) of metals in fish described in literature and range of concentrations found in muscle fish collected from the two sampling sites.

\begin{tabular}{|c|c|c|c|c|c|c|}
\hline \multirow[t]{2}{*}{ Organization } & \multicolumn{6}{|c|}{ Heavy Metals } \\
\hline & As & $\mathrm{Cd}$ & $\mathrm{Cr}$ & $\mathrm{Hg}$ & $\mathrm{Pb}$ & Reference \\
\hline $\begin{array}{l}\text { Ministry of Agriculture, } \\
\text { Fisheries and Food, } 1982\end{array}$ & 5.0 & - & - & - & - & \\
\hline $\mathrm{FAO} / \mathrm{WHO}$ & - & 0.5 & - & - & 0.3 & $\begin{array}{l}\text { FAO (1983) } \\
\text { WHO (1989) }\end{array}$ \\
\hline FAO 1989 & - & - & 0.5 & - & - & \\
\hline $\begin{array}{l}\text { EU Regulation } \\
1881 / 2006 / \mathrm{EU}\end{array}$ & - & - & - & 0.5 & - & \\
\hline $\begin{array}{l}\text { Range of metals in the } \\
\text { present Study }\end{array}$ & $0.025-0.33$ & 0.025 & $\begin{array}{l}0.025- \\
0.3\end{array}$ & $\begin{array}{l}0.01- \\
0.022\end{array}$ & $\begin{array}{l}0.25- \\
0.428\end{array}$ & $\begin{array}{l}\text { Present } \\
\text { study }\end{array}$ \\
\hline
\end{tabular}

Table $3 \mathrm{NHQ}$ values of $\mathrm{As}, \mathrm{Cd}, \mathrm{Cr}, \mathrm{Hg}$, and $\mathrm{Pb}$ exposure via consumption of fish from Marawi City and Tugaya, Lanao del Sur.

\begin{tabular}{clccccc}
\hline \multirow{2}{*}{ Location } & \multicolumn{5}{c}{ Samples } & \multicolumn{5}{c}{ Chemicals of Concern } \\
\cline { 3 - 7 } Marawi & Glossobius giuris & $\mathrm{As}$ & $\mathrm{Cd}$ & $\mathrm{Cr}$ & $\mathrm{Hg}$ & $\mathrm{Pb}$ \\
& Oreochromis niloticus & 0.378 & 0.008 & 0.082 & 0.098 & 815.437 \\
& Giuris margaritacea & 0.207 & 0.008 & 0.062 & 0.033 & 815.437 \\
Tugaya & Glossobius giuris & 0.399 & 0.008 & 0.027 & 0.043 & 815.437 \\
& Oreochromis niloticus & 0.320 & 0.008 & 0.027 & 0.033 & 848.055 \\
& Giuris margaritacea & 0.359 & 0.008 & 0.027 & 0.033 & 1396.029 \\
& & 0.087 & 0.008 & 0.027 & 0.043 & 815.437 \\
\hline
\end{tabular}


Table $4 \mathrm{HI}$ values of $\mathrm{As}, \mathrm{Cd}, \mathrm{Cr}, \mathrm{Hg}$, and $\mathrm{Pb}$ exposure via consumption of fish from Marawi City and Tugaya, Lanao del Sur.

\begin{tabular}{ccc}
\hline Location & Samples & $H I$ \\
\hline Marawi & Glossobius giuris & 816.00 \\
& Oreochromis niloticus & 815.75 \\
Tugaya & Giuris margaritacea & 815.91 \\
& Glossobius giuris & 848.44 \\
& Oreochromis niloticus & 1396.46 \\
\hline
\end{tabular}

\section{Discussion}

Heavy metals are among the pollutants which received the most attention and are considered to be in the most dangerous category of pollutants (Paudel et al. 2016). In most cases, mean values of heavy metals in the present study are considerably lower than the standard permissible level, except for $\mathrm{Pb}$. The same result was obtained by Paudel et al. (2016) in their study on the analysis of heavy metals in some commercially important fishes. The recorded higher $\mathrm{Pb}$ concentration could be attributed to the different sources of $\mathrm{Pb}$ pollution in the environment which include effluents and emissions from vehicles running on leaded petrol, use of lead sheets by roofers, as well as the use of paints and anti-rust agents. Moreover, results suggested that predators or scavengers would be at risk from lead if they ate it in the wild. Lead is a neurotoxin that causes behavioral deficits in vertebrates (Weber et al., 1997) and can decrease survival, growth rates, learning, and metabolism (Eisler, 1996; Burger and Gochfeld, 1996; Paudel et al. 2016). Levels of 50 $\mathrm{ppm}$ in the diet can cause reproductive effects in some predators, and dietary levels as low as $0.1-0.5 \mathrm{ppm}$ are associated with learning deficits in some vertebrates (Burger and Gochfeld, 1996). In the case of the present study, all tested organisms from all areas have high NHQs for lead. These results mean that systemic toxicity has a high likelihood to occur when lakeshore communities continue consuming the contaminated organisms.

Since the pollutants of concern are found to be co-occurring in all the tested samples, one can already say that the fishes are not safe for consumption based on the NHQs of Pb alone. This is backed up by the values obtained from the computation of the HI. The HI values imply serious consideration for corrective measures to regulate consumption, and to bring the concentrations to safe levels, particularly for all areas.

Four ( $\mathrm{As}, \mathrm{Cd}, \mathrm{Cr}$, and $\mathrm{Hg}$ ) among the five pollutants of concern have an NHQ that is less than one. This means that there is no health risk associated with oral exposure to each of these chemicals via ingestion of fishes taken from the two areas. However, $\mathrm{Pb}$ has an NHQ that exceeded one for all fish samples obtained from all locations. The ingestion of $G$. giuris, O. niloticus, and G. margaritacea samples collected from Marawi City, and Tugaya, Lanao del Sur pose a high likelihood for adverse non-carcinogenic impacts specifically by $\mathrm{Pb}$. This does not necessarily hold true for the whole of Lake Lanao however, due to limitations related to representativeness.

The health risk was only assessed in consideration of exposure to $\mathrm{As}, \mathrm{Cd}, \mathrm{Cr}, \mathrm{Hg}$, and $\mathrm{Pb}$ via ingestion of fish. However, there are other pathways of heavy metal contamination such as ingestion of and dermal exposure to lake water. Moreover, there may also be presence of other heavy metals that were not included in the analysis and are present in the fish samples. The likelihood of risk may even be higher. With the above data, it is recommended that risks posed by the consumption of fish from Marawi City and Tugaya, Lanao del Sur should be managed at the soonest possible time, especially in consideration of vulnerable groups such as children, pregnant women and their developing fetus, and people with existing health conditions (Asante-Duah, 2017). Consumption of fish from the areas where the sampling was conducted should be regulated, if not banned, until the risk has been managed. To come up with a more realistic health risk assessment, it is recommended that the actual consumption rate of $G$. giuris, $O$. niloticus and $G$. 
margaritacea be determined through a survey that is representative of age, all types of consumers (e.g., recreational, commercial, and subsistence fish consumption), and more areas.

\section{Acknowledgements}

Authors wish to express their sincere thanks to the Department of Science and TechnologyPhilippine Council for Health Research and Development (DOST-PCHRD) for the funding of this project. Gratitude is due to Mariel Grace Bucog and Mary June Andale for the help during the sampling and for technical and administrative assistance.

\section{References}

Alidadi, H., Tavakoly S., Garaati Oftadeh, Z., Mohamad, B., Shamszade, T., Fakhari, M., 2019. Health risk assessments of arsenic and toxic heavy metal exposure in drinking water in northeast Iran. Environmental Health and Preventive Medicine, 24, 59. https://doi.org/10.1186/s12199-019-0812-x

Angagao, N.B., Quiao, M. L. D., Roa, E., Prado, G., 2017. Water Quality Assessment of the South-Eastern Part of Lake Lanao, Philippines. International Letters of Natural Sciences 63. https://doi.org/10.18052/www.scipress.com/ILNS.63.34

Asante-Duah, K. 2017. Chemical Risk Characterization. In: ASANTE-DUAH, K. (ed.) Public Health Risk Assessment for Human Exposure to Chemicals. Dordrecht: Springer Netherlands. https://doi.org/10.1007/978-94-024-1039-6

Béné, C., Barange, M., Subasinghe, R., Pinstrup-Andersen, P., Merino, G., Hemre, G., Williams, M., 2015. Feeding 9 Billion by 2050 - Putting Fish Back on the Menu. Food Security 7 (2): 261-74. https://doi.org/10.1007/s12571-015-0427-z.

Burger, J., Gochfeld, M., 1996. Heavy Metal and Selenium Levels in Franklin's Gull (Larus Pipixcan) Parents and Their Eggs. Archives of Environmental Contamination and Toxicology 30 (4): 487-91. https://doi.org/10.1007/BF00213400

Clayton, C. A., Pellizzari, E. D., Quackenboss, J. J., 2002. National Human Exposure Assessment Survey: Analysis of exposure pathways and routes for arsenic and lead in EPA Region 5. Journal of Exposure Science \& Environmental Epidemiology, 12, 29-43. https://doi.org/10.1038/sj.jea.7500198

Dœlsch, E., Van De Kerchove, V., Saint Macary, H., 2006. Heavy metal content in soils of Réunion (Indian Ocean). Geoderma, 134, 119-134. https://doi.org/10.1016/j.geoderma.2005.09.003

Duruibe, J., Ogwuegbu, M., Ogwuegbu, O. C., Egwurugwu, J.N., 2007. Heavy Metal Pollution and Human Biotoxic Effects. International Journal of Physical Sciences 2 (5): 11218.

EI Nemr, A., El-Said, G. F., Khaled, A., Ragab, S., 2016. Distribution and ecological risk assessment of some heavy metals in coastal surface sediments along the Red Sea, Egypt. International Journal of Sediment Research, 31, 164-172. https://doi.org/10.1016/j.ijsrc.2014.10.001

Eisler, R., 1996. Silver Hazards to Fish, Wildlife, and Invertebrates: A Synoptic Review. 32. US Department of the Interior, National Biological Service.

FAO (Food and Agriculture Organization of the United Nations), 2020. Aquaculture growth potential in the Philippines. WAPI factsheet to facilitate evidence-based policymaking and sector management in aquaculture. FAO, http://www.fao.org/3/ca8810en/ca8810en.pdf, January 20, 2021.

FAO/WHO, 1992. Codex Alimentarius Commission, Standard program Codex Committee on Food Additives and Contaminants. 24th Session, Hague, pp. 23-28.

Federal Environmental Protection Agency. 2003. Guidelines and Standards for Environmental Pollution Control in Nigeria. p. 238. [Google Scholar]

Ho, L. T., Goethals, P.L.M., 2019. Opportunities and Challenges for the Sustainability of Lakes and Reservoirs in Relation to the Sustainable Development Goals (SDGs). Water 11 (7): 1462. https://doi.org/10.3390/w11071462. 
Iqbal, J., Shah, M.H., 2013. Health Risk Assessment of Metals in Surface Water from Freshwater Source Lakes, Pakistan. Human and Ecological Risk Assessment: An International Journal, 19, 1530-1543. https://doi.org/10.1080/10807039.2012.716681

Ministry of Agriculture, Fisheries and Food, 1982. Survey of arsenic in food, the eighth report of the steering group of food surveillance, the working party on the monitoring of foodstuffs for heavy metals, Food surveillance paper No. 8, HMSO

Listrat, A., Lebret, B., Louveau, I., Astruc, T., Bonnet, M., Lefaucheur, L., Picard, B., Bugeon, J., 2016. How Muscle Structure and Composition Influence Meat and Flesh Quality. The Scientific World Journal 2016 (February): e3182746. https://doi.org/10.1155/2016/3182746.

McCluggage, D., 1991. Heavy Metal Poisoning, NCS Magazine, Published by The Bird Hospital, CO, U.S.A. (www.cockatiels.org/articles/Diseases/metals.html).

Molina, V., 2012. Non-carcinogenic health risk of heavy metal in mudfish from Laguna Lake. Science Diliman, 24, 23-32.

Obasohan, E. E., 2007. Heavy Metals Concentrations in the Offal, Gill, Muscle and Liver of a Freshwater Mudfish (Parachanna Obscura) from Ogba River, Benin City, Nigeria. African Journal of Biotechnology 6 (22). https://doi.org/10.5897/AJB2007.000-2419

Öztürk, M., Özözen, G., Minareci, O., Minareci, E., 2009. Determination of Heavy Metals in Fish, Water and Sediments of Avsar Dam Lake in Turkey. Journal of Environmental Health Science \& Engineering 6 (2): 73-80.

Paudel, P. N., Pokhrel, B., Kafle, B.K., Gyawali, R., 2016. Analysis of Heavy Metals in Some Commercially Important Fishes of Kathmandu Valley, Nepal. International Food Research Journal 23 (3).

Tamele, I.J., Vázquez Loureiro, P., 2020. Lead, Mercury and Cadmium in Fish and Shellfish from the Indian Ocean and Red Sea (African Countries): Public Health Challenges. Journal of Marine Science and Engineering, 8. https://doi.org/10.3390/jmse8050344

Tchounwou, P.B., Yedjou, C.G., Patlolla, A.K., Sutton, D.J., 2012. Heavy Metals Toxicity and the Environment. EXS 101: 133-64. https://doi.org/10.1007/978-3-76438340-4_6. https://doi.org/10.1007/978-3-7643-8340-4_6

USEPA (United States Environmental Protection Agency), 2020. IRIS Assessments. Washington, DC, USA: Integrated Risk Information System Program-USEPA, https://cfpub.epa.gov/ncea/iris/search/basic/index.cfm,

USEPA (US Environmental Protection Agency), 1989. Risk Assessment Guidance for Superfund, Vol 1. Human Health Evaluation Manual. Part A (interim final), EPA/540/189/002, Office of Emergency and Remedial Response, Washington, DC, USA, January 18, 2021.

Weber, D.N., Dingel, W.M., Panos, J.J., Steinpreis, R.E., 1997. Alterations in Neurobehavioral Responses in Fishes Exposed to Lead and Lead-Chelating Agents. American Zoologist 37 (4): 354-62. https://doi.org/10.1093/icb/37.4.354

World Health Organization, 1981. Arsenic, Environmental Health Criteria 18 International Programme on Chemical Safety, World Health Organization, Geneva.

WHO (World Health Organization) vol. 1. Recommendation WHO; Geneva: 1985. (Guidelines for Drinking Water Quality). p. 130. [Google Scholar]

WHO, 1989. Heavy metals environmental aspects. Environmental Health Criteria No. 85, World Health Organization, Geneva, Switzerland. 